\title{
Peafowl Production
}

\author{
Fatma Yenilmez ${ }^{1, a, *}$ \\ ${ }^{I}$ Tufanbeyli Vocational School, Çukurova University, 01640 Tufanbeyli/Adana, Turkey \\ ${ }^{*}$ Corresponding author
}

\begin{tabular}{l|l}
\hline A R T I C L E I N F O & A B S T R A C T \\
\hline Review Article & $\begin{array}{l}\text { Peafowl is a common name of three species of the Phasianidae family. It is known as a sacred bird } \\
\text { in many Asian countries and India that is the homeland of the peafowl. They live in groups and } \\
\text { prefer cultivated areas and forests where they can find more food in nature. They feed on cereal } \\
\text { grains, insects, fruits, leaves, seeds. It has a strong structure and adapts very well to different } \\
\text { climates. Because of this feature can be produced anywhere in the world. There are commonly } \\
\text { known three different types of peafowl. Blue (Indian) Peafowl (Pavo cristatus), Green Peafowl (Pavo } \\
\text { muticus) and Congo Peafowl (Afropavo congoensis). The most recognizable species of them is the } \\
\text { Indian Peafowl. Peafowl has always been the center of attention with its striking, bright and eye- } \\
\text { Accepted : }: 09 / 12 / 2019 \\
\text { catching colors on its body and long tail, and it is natural wonders. Therefore, they are especially } \\
\text { indispensable members of zoos and ornamental gardens. Although peafowl are usually produced for } \\
\text { their beautiful appearance, their meat is also very tasty and beneficial. This article is prepared to give } \\
\text { brief information about peafowl. }\end{array}$ \\
$\begin{array}{l}\text { Keywords: } \\
\text { Exotic birds } \\
\text { Ornamental bird } \\
\text { Peafowl }\end{array}$ &
\end{tabular}

Morphological features

Peafowl species

\section{Introduction}

Peafowl known as exotic bird in many parts of the world is native to India, Java, Assam, Burma, Siam, Ceylon and Malaya (Anonymous, 2019a). Phoenicians are the first brought them from India to Syria and Egypt about 3,000 years ago. The Great Alexander was introduced them to Greece about 600 years later (Anonymous, 2019b). Peafowl is known with spectacular colors of peacocks body and tail in many parts of the world. But their meat was served to the banquets of the wealthy in Roman times. English barons offered roasted peafowl to their guests in the Middle Ages. So they spread to the world as symbols of wealth and power.

The peafowl is the common name for members of tree species of large birds of the pheasant family Phasianidae, Pavo cristatus (Indian peafowl), Pavo muticus (green peafowl) and Afropavo congoensis (Congo peafowl). It is known as a sacred bird in India and many Asian countries. They are widely produced in most zoos and ornamental gardens, because of their bright color of feather and wonderful tail. The males of peafowl have crested heads, long legs, heavy wings, and spectacular colored plumage.
Peacock have long, brilliant, tail feathers that is named train feathers and can be erected and fanned out and have iridescent, eye-like spots (Anonymous, 2019c) (Figure 1). For this reason, more people recognize the peacocks, not peahen. Peacocks are the largest flying birds among all the birds (Anonymous, 2019d) (Figure 2). This is not known so many people, just as many things are not known about these birds.

This text intended to give brief information about wonderful birds to introduce to them who are wondering them.

\section{Scientific Classification*}

$\begin{array}{lll}\text { Kingdom } & : & \text { Animalia } \\ \text { Phylum } & : & \text { Chordata } \\ \text { Class } & : & \text { Aves } \\ \text { Order } & : & \underline{\text { Galliformes }} \\ \text { Family } & : & \underline{\text { Phasianidae }} \\ \text { Subfamily } & : & \underline{\text { Phasianinae }}\end{array}$




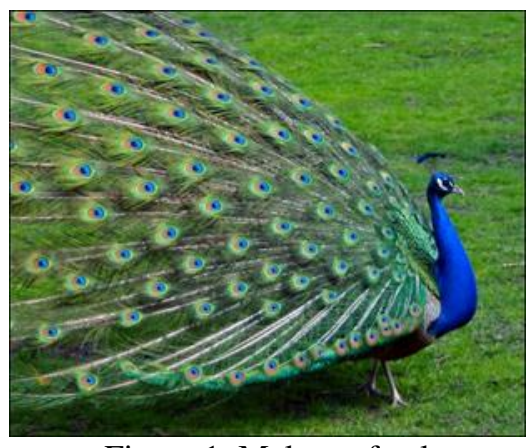

Figure 1. Male peafowl

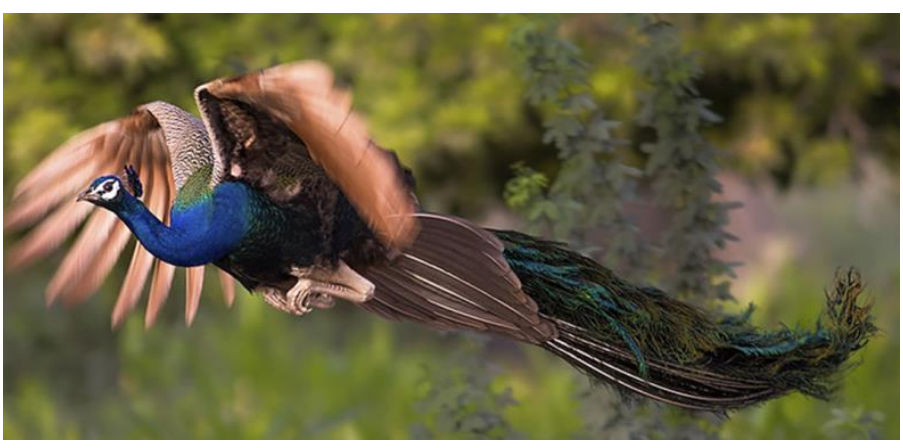

Figure 2. Flying peacock
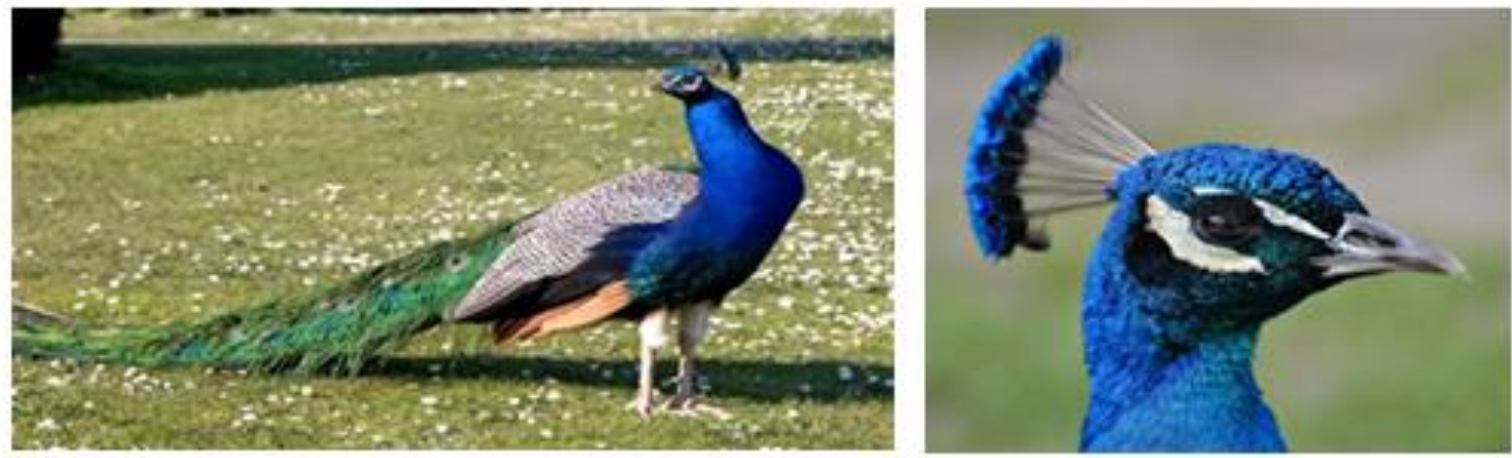

Figure 3. Body and head structure of a peafowl
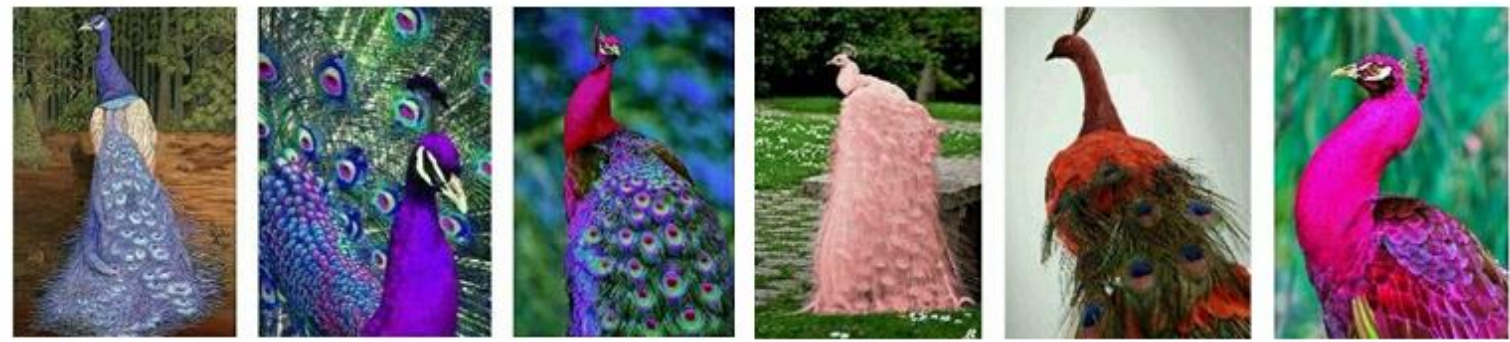

Figure 4. Different colors of peafowl
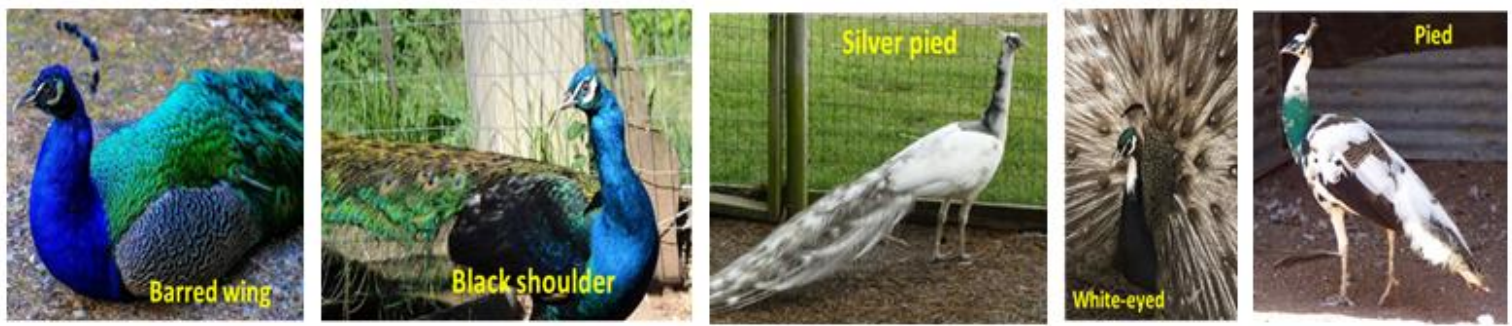

Figure 5. Peafowl body patterns

\section{Morphological Features}

The peafowl can be produced in many parts of the world because they have a strong structure and adaptability. It has a relatively long neck and a small head, short wings, very strong legs, high claws and average tail length. They have crown-shaped feathers on his head, expanding towards the ends and create a very beautiful image. (Anonymous, 2019f) (Figure 3).

The peafowl has 15 known colors: Blue, green, white, purple, cameo, charcoal, opal, bronze, peach, midnight, jade, taupe, sonja's violeta, hazel and indigo (Nelson, 2019) (Figure 4).
And they have 5 known body patterns: Barred wing, Black shoulder, Pied, White-eyed, and Silver pied (Nelson, 2019) (Figure 5).

The name of the peafowl is used for both sexes. The male is called peacock, the female is peahen and the chick is peachick (Anonymous, 2019d). The only male peacock tail is long and spectacular. The peacock spreads its tail which contains over 200 shimmering feathers like a fan to woo the female in the mating period and is known for its beautiful tail (Figure 6). The tail is the same length as the female for 1-1.5 years. It continues to grow for 5-6 years and can reach 1.5 meters or more (Figure 7 ). 


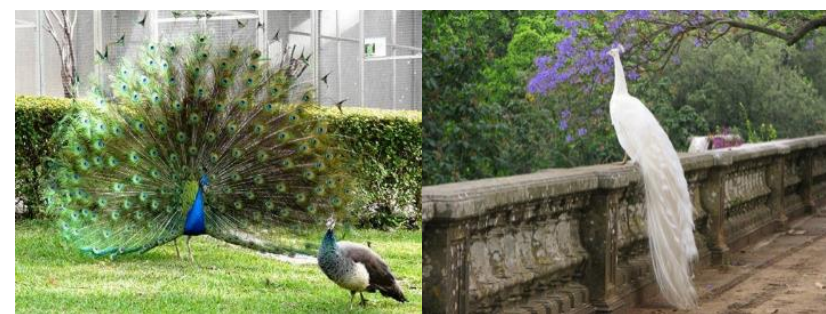

Figure 6. Peacock courting to the female

Figure 7. Peacock tail

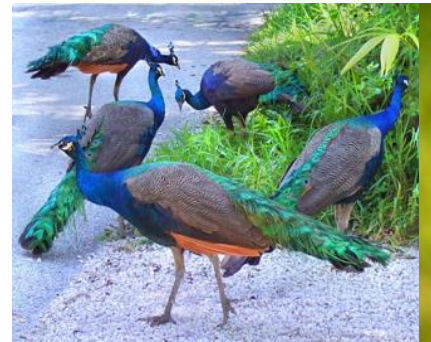

Figure 8. Peafowl group

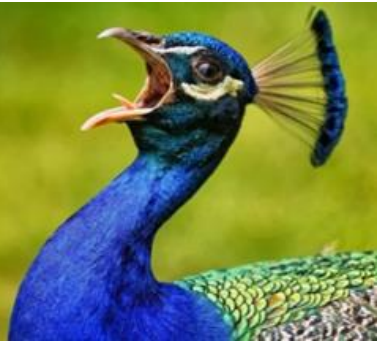

Figure 9. Crowing peacock
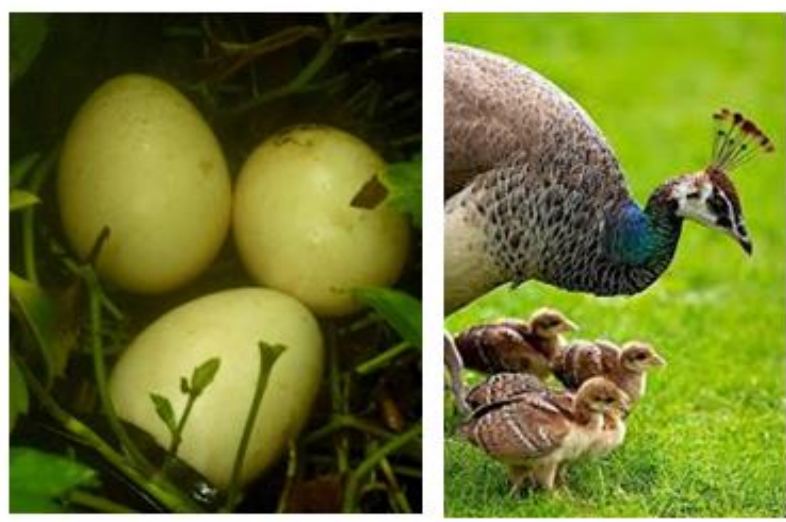

Figure 10. Peahen eggs and peachicks

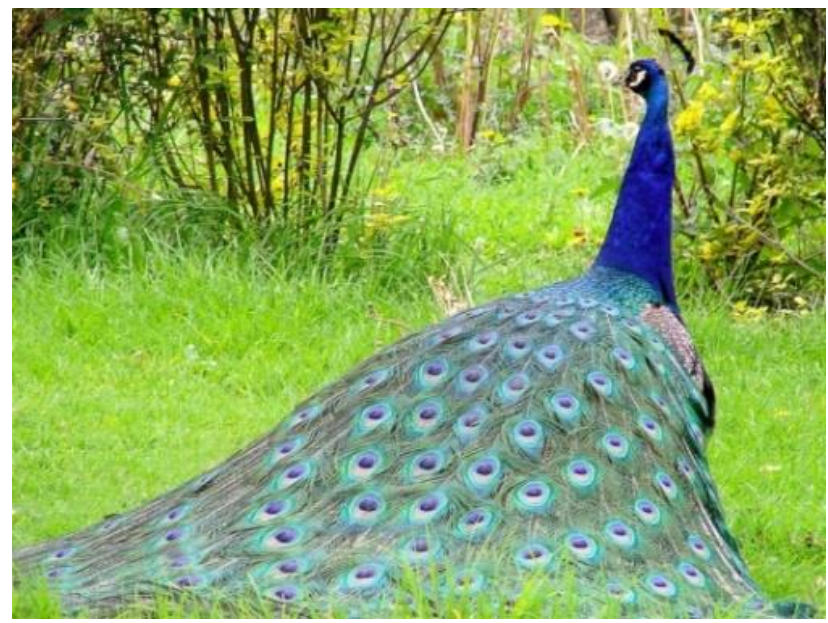

Figure 11. Blue (Indian) Peacock

Peacocks weigh 9-13 kilograms and peahens weigh 69 kilograms (Anonymous, 2019e). The average lifetime is approximately 35 years. They live in groups and each group has 1 male and 5-6 females (Figure 8). Males reach sexual maturity at the age of 2-3 and females begin to lying at age 2. Reproduction periods are from April to August. Peacocks call in the early morning and late evening, and practically all day during the breeding season. His voice is treble and screaming (Anonymous, 2019g) (Figure 9).
Peacocks are considered polygamous. A mature peacock can be mated with five peahens. Peahens must be active and healthy, have good feather quality, straight legs and toes, and clear eyes. After mating, the female starts laying eggs and sits on it for incubation. One peahen lay down about 7-10 eggs a year. Eggs are light brown colored (Figure 10). Hatching takes 28-30 days after the female starts to sit on the eggs (Hopkins, 2019; Gleaves, 1988).

Peafowls must be kept in rural areas, out of town. Because of their sounds are very high-pitched and disturbing. At least 25 square meters per bird is required for peafowl breeding. This area is important to prevent diseases and to take precaution fighting among birds. And the pens must be at least 2,5 meters high so that the peacock can vent its tail. The tail may be injured if there is not enough space. Wooden pens may be the best way to protect them from the cold and to live comfortably (Anonymous, 2019h).

\section{Nutrition}

Peafowl are omnivorous, consumes insects and vegetation in nature. Popular foods are plant parts, flower petals, seed heads, insects and other arthropods, reptiles, and amphibians. They find and consume the food they need in the natural environment. In captivity peafowl are usually fed a supplemented feed by their caretaker. The young peafowl are needs balanced feed ration including adequate vitamins, trace minerals and amino acids. Turkey rations are perfect feed for peafowl, because their physiology is similar to young turkeys. They can be fed for 4 months with starter (28\% protein) and grower feed. The last growth feed (14\% protein) can be continued until 1 year of age and can be used for adults. Young peacock can be fed with millet or mixed small grains. Whole meal cereals can be fed when grown, but only cereals are insufficient for them and need to be fed regularly with vegetables, leaves and grasses that are available in their natural habitats. Peafowls love insects and consume them to meet their protein needs. However, if there are not enough insects, it is necessary to provide a protein supplement that is meat-based feed such as cat food. In addition, their diet should include vitamin and mineral supplements should also be done when needed. Water must have always ready (Anonymous, 2019i; Gleaves, 1988).

\section{Peafowl Species}

There are three different types of peafowls.

- $\quad$ Blue (Indian) Peafowl (Pavo cristatus)

- Green Peafowl (Pavo muticus)

- Congo Peafowl (Afropavo congoensis)

The most recognizable species of the peafowl is the Indian Peafowl.

\section{Blue (Indian) Peafowl (Pavo cristatus)}

Blue peafowl are known as Indian peafowl, are large and brightly colored birds native to Sri Lanka and India, but can also be found naturally in Nepal, Assam, Pakistan, Kashmir, Nagaland, Burma, Java, Ceylon, Malaya, and the Congo. Peacocks are a larger sized bird with a length from bill to tail of 100 to $115 \mathrm{~cm}$ and weigh are $4-6 \mathrm{~kg}$. The peahens are smaller at around $95 \mathrm{~cm}$ in length and weigh 2.75-4 kg (Anonymous, 2019e) (Figure 11). The male necks and breasts are usually a bright blue and their trains 
are an iridescent formation of multiple colors featuring eye-spots. Females are brown, grey, and cream-colored. Chicks are usually a light yellow to brown color. Average lifespan is 15 years. Range age at sexual maturity of male is 2-3 year and female is 1-3 years. The breeding season is between April and September. Average eggs production is 5 per peahen (Anonymous, 2019j).
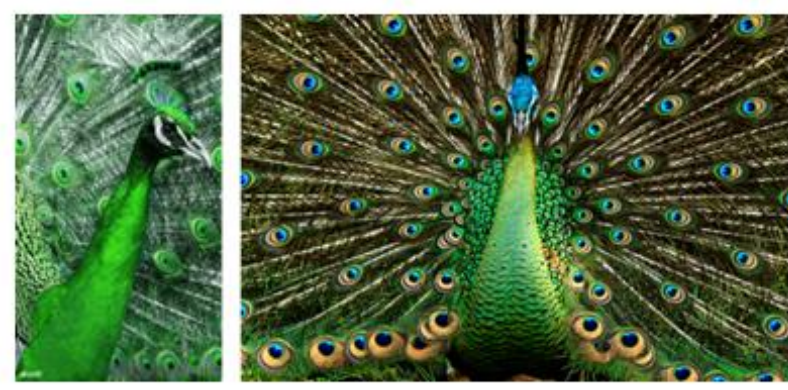

Figure 12. Green Peacock

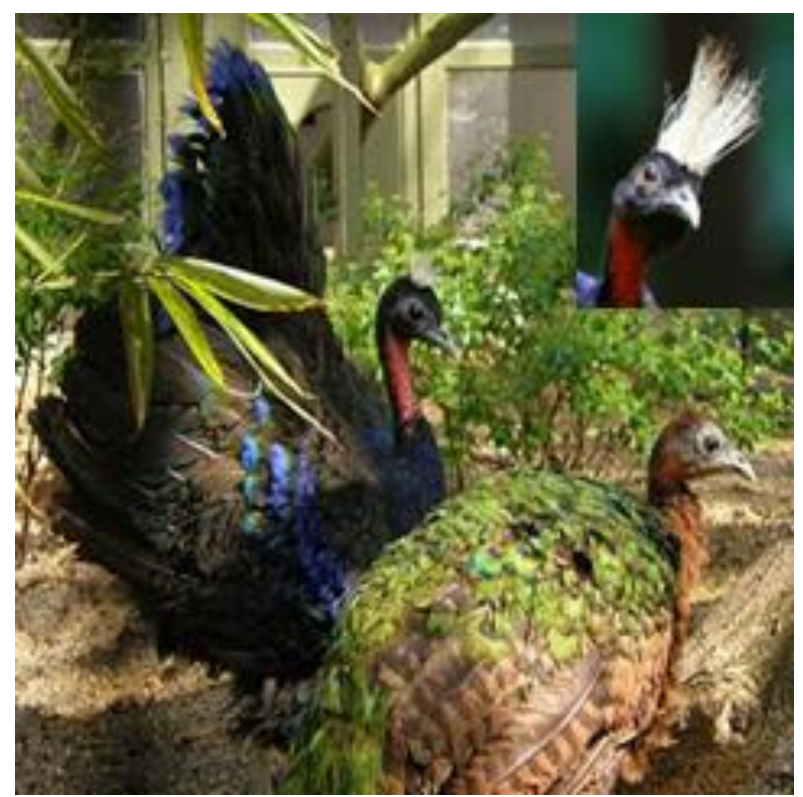

Figure 13. Congo Peafowl

\section{Green Peafowl (Pavo muticus)}

Green Peafowl called as the Java peafowl are lives up to 2000-3000 meters in Southeast Asia. It is mostly found in open woodland and forest edges. At the same time, rivers and surrounding wetlands are places where they are frequently seen. They are similar to the Indian Peafowl but have some differences in plumage and head. The adult males have brilliant green plumage, blue shoulders, dark brown and long tail feathers, dark brown with green tinge on breast and flanks. They have a long upright blue-black crest on head. The lengths of peacock are 1.8-3 m and peahens $1-1.1 \mathrm{~m}$ and weigh $3.9-5 \mathrm{~kg}$. They are large birds, amongst the largest living galliforms in terms of overall size. The female lays 3-8 eggs per period. Their chicks are larger and greyer than the Indian Peafowl, and can fly about two weeks after hatching. (Anonymous, 2019e; Anonymous, 2019k). (Figure 12).

P.m. spicifer (India, Bangladesh and Burma), P.m. imperator (Burma, Thailand, China, Vietnam and Laos) and P.m. muticus (Java) are the subspecies of them (Anonymous, 2019k).

\section{Congo Peafowl (Afropavo congoensis)}

The Congo peafowl known as the African peafowl is a species of peafowl native to the Congo Basin. It was discovered in 1936 and the wild population is estimated that 2500-9000 adults. They have physical characteristics of both the peafowl and the guinefowl. They are less impressive and smaller than the other peafowl. They have bare red neck skin, grey feet, and a black tail with fourteen tail feathers. Its crown is different from others and adorned with vertical white elongated hair-like feathers. The peacock's feathers are deep blue with a metallic green and violet tinge. The peahens' feathers are brown and green for camouflage. The peacock of this species is a large bird of up to $64-70 \mathrm{~cm}$ in length and $1.5 \mathrm{~kg}$ in weight. The peahen is also $60-63 \mathrm{~cm}$ in length and 1.2 kilograms in weight. The Congo peacock is monogamous, but there is not enough information about wildlife. The male is ventilated its tail during the mating season like as others. The peahen is lay average 1-4 eggs with dark brown colored in a period (Anonymous, 2019e; Anonymous, 2019l) (Figure 13). Fruits and invertebrates (larvae, earthworms, snails, millipedes, spiders, and a variety of insect's spiders) are occurs their mainly diet (Anonymous, 20191).

\section{Conclusion}

Peacocks that attract attention with their visual beauty are known and loved by everyone. Although these beautiful birds are widespread in the world, their production is limited to zoos and ornamental gardens. Therefore, scientific studies are needed to increase and spread the producing of these birds.

\section{References}

Anonymous, 2019a. What is The Difference Between a Peacock and Peafowl? http://www.peafowl.org/Access on: 23.11.2019.

Anonymous, 2019b. Common Peafowl. https://nationalzoo.si.edu /animals/common-peafowl. Access on: 08.12.2019.

Anonymous, 2019c. Peafowl. https://www.newworldencyclopedia.org /entry/peafowl. Access on: 08.12.2019.

Anonymous, 2019d. Indian peafowl. https://kids.nationa lgeographic.com/animals/birds /indian-peafowl/. Access on: 23.11.2019.

Anonymous, 2019e. Peafowl. https://en.m.wikipedia.org /wiki/Peafowl. Access on: 23.11.2019.

Anonymous, 2019f. Game Birds - Wild. https://www.decaturparks.org/scovill-zoo/birds/game-birds-wild/. Access on: 23.11.2019.

Anonymous, 2019g. Peafowl. https://animals.sandiegozoo.org /animals/peafowl. Access on: 23.11.2019.

Anonymous, 2019h. 5 Essential Tips for Keeping Peacocks as Pets. https://www. wideopenpets.com/5-essential-tips-forkeeping-peacocks-as-pets/. Access on: 08.12.2019.

Anonymous, 2019i. Peafowl peacock. https://animalcorner.co.uk /animals/peafowl/. Access on: 23.11.2019.

Anonymous, 2019j. Pavo Cristatus, Indian Peafowl. https://animaldiversity.org/accounts/ Pavo_cristatus/. Access on: 08.12.2019.

Anonymous, 2019k. Green Peafowl, Pavo Muticus. http://www.oiseaux-birds.com/card-green-peafowl.html. Access on: 08.12.2019.

Anonymous, 20191. Congo Peafowl. https://www.domesticforest.com /congo-peafowl/. Access on: 08.12.2019. 